\title{
On Financial Control and Corporate Governance Structure
}

\author{
Li He \\ School of Accounting, Shandong Economic University \\ 7366 Er Huan East Road, Jinan 250014, China \\ E-mail: helizh@163.com
}

\begin{abstract}
This paper mainly analyzes the relationship between corporate governance structure and financial control. Then it gives some suggestions combined with current situation in China to improve the corporate governance structure to protect the financial control system.
\end{abstract}

Keywords: Corporate governance structure, Financial control, Insiders control

\section{The relationship between financial control and governance structure: part and whole}

Modern theory figures that the company is a consortium contract formed by a range of stakeholders. These stakeholders include shareholders, creditors, managers, employees, customers, suppliers, government and so on. The corporate governance structure just is a set of formal or informal, internal or external system used to coordinate their relationship, to ensure that the company make decisions more scientific, to safeguard the interests of all parties. The function of corporate governance structure is to distribute rights, responsibilities and interests. The "right" refers to the residual control right, which decides the use of assets not provided by law or contract. It determines the residual income right, which is the basis of corporate governance. The financial control is the core of the corporate control because corporate finance is a comprehensive reflection of production and the focus of all parties' interest. The company's financial control system can be regarded as a special contract about the residual financial control right. It is constituted by a series of systems that can control financial activities and coordinate financial relationship. So that financial control is a refinement of corporate governance structure, and an important part of governance structure.

The company's financial control mainly involves investors' financial control, operators' financial control and professional financial control in a perfect corporate governance structure.

\subsection{Investors' financial control}

The operators' interests are inconsistent with investors'. Investors should control operators in order to achieve their goal that is to increase their capital value. The company's investors include shareholders and creditors. They respectively provide equity capital and debt capital. Shareholders are responsible for liabilities of the company by equity capital and enjoy owner's equity. The performance of their financial control includes the right to choose directors and supervisors, the power to decide major financial activities, the power to determine financial budget, the power to dispose the registered capital, the right to dispose the reward of directors and supervisors, and so on. The features of these financial control rights are usually infrequent, involving change of equity, huge transaction amount and having far-reaching impact on the company's development. Creditor's financial control has two main aspects. First, the creditors don't directly intervene the company's finance when the borrowing company operates normally. They only control the company's financial activities by monitoring the implementation of the credit contract; Second, the creditor will put a relatively dominant position in the company's financial control if the company is unable to repay debt.

\subsection{Operators' financial control}

While ownership and operating right are separated, the operators' financial relationship is mainly derived from the relationship between investors and operators, and between the operators and managers at all levels. Operators control and coordinate the economic interests involved by directly or indirectly means in order to ensure the company's maximum value. The board of directors and managers forms operators' financial control. The board of directors plays a major role. Its financial control include the right to choose managers, the power to formulate investment and financing programs, the power to formulate financial budget, the power to formulate the programs about increasing or decreasing registered capital and distributing corporate bonds, the power to formulate separation and dissolution programs, the power to decide the managers reward. Managers are in the enforcement position. Their financial control mainly includes the enforcement power, the right to choose 
financial managers and the power to decide some recurrent or unexpected financial matters.

\subsection{Professional financial control}

The investors achieve their ultimate goal through the operators' financial decision-making, organization and coordination. The operators' financial decision-making and coordination are implemented through the financial managers and finance officers. Therefore, professional finance is an integral part of the company as an operational finance at the lowest financial level. Its financial control is the further decomposition and commission of the operators' financial control. It mainly includes the right to schedule daily fund, the power to perform exchange clearing, the right to participate in financial decision-making, the right to monitor the implementation of financial decision-making process, and so on.

Three levels of the company's financial control have different emphases in the whole corporate governance structure. But their ultimate goals are same that is to achieve maximum value of the company. Professional financial manages cash flow to ensure the smooth implementation of the operators' finance. On one hand, operators' finance makes the correct decision to ensure high-yielding, high efficiency and orderly operation of the enterprise under the supervision of the inventors. On the other hand, it reduces agency costs at all levels as much as possible through rational organization and coordination, so the operating cost of organizational system will be the smallest. Investors' financial control is an indirect binding mechanism, which implements monitoring and incentive programs through the company's governance structure to ensure the agency costs between the operators and investors be of the minimum and the company achieve the maximum value. The harmonization of three levels is the key to effect corporate governance.

\section{The link between financial control and corporate governance structure}

Since the relationship between financial control and governance structure is part and whole, they should coordinate with each other. On one hand, financial control should correspond to corporate governance model. On the other hand, good financial control is assurance to handle the relationship of various stakeholders correctly and to improve the corporate governance. So we should promote its conscious activity.

Currently the corporate governance models have mainly three types in the world. Their corresponding financial control models have different characteristics.

\subsection{Operator-led financial control model}

This model adapts to the market-oriented corporate governance structure that is represented by Britain and America. In such a governance structure, the president as an agent is at the company's dominant position because of highly dispersed shareholding. There is no single shareholder or creditor willing to pay costs to monitor "collective goods". Moreover operator can directly control the funds movement, which allows operators' financial control to be at the core of the company's financial position. Investors find it difficult to encroach on the company's financial decision-making. Managers increasingly dominate the corporate property rights. Being lifted out of original property, corporate property become independent. Of course, this does not mean that the financial management activities of inventors does not exist, on the contrary, it indicate the importance of inventors' financial control. The asymmetry of information will inevitably lead to the asymmetry of power as well as constraints and incentives become important issues. For weakening of internal controls, all relevant subjects are bound to seek the form of external market monitoring in order to enhance the external financial control to protect their own interests. The maturing of securities market, managers market and labor market system adapts to this request.

\subsection{Investor-led financial control model}

This model adapts to the bank-oriented corporate governance structure represented by Japan and Germany. In such a governance structure, all stakeholders have a voice, which achieves the goal of monitoring agent. For example supervisory board has extensive rights in Germany and its members are all staff and shareholder representatives. Furthermore, high proportion of corporate ownership has a direct monitor power. Particularly banks are not only creditors, but also major shareholders, who often directly send directors to the company's internal power structure to strengthen the monitoring on managers. This enables companies make inventors' finance as the core to carry out the operation and management. Of course, this does not mean that the operators' financial control is dispensable. But operators' financial control must be carried out around the inventors' financial, so it has been greatly restricted in the operation.

\subsection{Owner-led financial control model}

This model adapts to the family-controlled corporate governance structure represented by the Southeast Asian 
countries and South Korea. It is a financial operation mechanism between inventors' finance and operators' finance. In such a governance structure, the company's ownership and management rights do not separate and the company is combined with the family. The family gets hold of the company's control rights. Owner-led financial control model accommodates the entire contents of inventors finance and operators finance to manage together, so that the agency costs between inventors and operators will be the smallest. The economic benefits from enterprise asset operations can be translated into shareholders' wealth. Its disadvantage is that weakened internal oversight may harm the interests of small shareholders. It can be resolved through the improvement of external market monitoring system and the strengthening of inventors' externally financial control.

\section{Financial control and corporate governance structure in China}

Most listed companies of China restructured from state-owned enterprises. Their greatest feature is that the state-owned shares due to the dominance, shares concentrate highly and outstanding shares have low percentage. As the state-owned shares are lack of personification of practitioners, namely "the absence of owner", the managers become the company's actual owners to some extent. General meeting of stockholders and board of directors can't control the operators. Most of the members of the board are the company's senior managers who primarily come from the state-owned enterprises as promoters. They implement specific management and are nominally on behalf of shareholders. So the operators control the decision-making and supervision rights of the company. This governance structure is called "insiders control model of governance". In this model of governance structure, operators' financial control is at the core of financial control and investors are difficult to encroach upon the corporate financial decision-making. Corporate managers increasingly determine the property rights. In addition, the external market monitoring system in China is not perfect, so the investor's financial control is basically not effective.

There was a misunderstanding in past. When a company's financial control was failure, people used to find the reasons from the system of mutual containment, supervision and review control procedures, etc. They wanted to use financial control deficiencies to explain the matter. They did not fully aware the financial control detached from governance structure and inadequate governance structures are also the major reasons to failure. The "CAO" event is a typical example. In December 2004, China Aviation Oil (Singapore) Corporation Ltd was forced to file for bankruptcy protection because manager Chen Jiu-lin carried out oil derivatives trading and had a loss of 550 million U.S. dollars. Many people suspect that CAO hadn't internal control system after the case. In fact, its control system was not different from other international oil companies. Ernst and Young made the most important "Risk Management Manual", which is very detailed. However, these systems became a mere formality and did not play any role in practice. The underlying reason was the corporate governance structure was imperfect, the board performed no function, and the corporate leaders had over centralized power that led to fatal policy blunders. Therefore, the setting of financial control must be integrated with the perfection of governance structure. Only under perfect corporate governance environment, a good financial control system can really play its role in enhancing the company's financial operating efficiency and effectiveness, or it will only be a mere formality.

\section{Some suggestions}

We can provide some protection to the improvement of financial controls from design of the corporate governance structure.

\subsection{Basic requirements on the setting of financial control should be required in the corporate governance standards}

Financial control system is designed by managers and reflects the manager's intention. While the manager's objective function is differ from investors' and other stakeholders' objective function. In order to ensure the company's operation and safeguard all stakeholders' rights, basic requirements on the setting of financial control should be required in the corporate governance standards. So the objectives of financial control and corporate governance will be consistent.

\subsection{The central position of board of directors should be guaranteed through the building of corporate governance mechanism}

Investors can take advantage of residual control rights to make decisions when the matters occur that legal or contract does not provide. But dispersed ownership makes cost very high if inventors exercise power. In fact that the burden of exercise controlling right mainly rests on the board of directors. Financial control is the important measures of the board to inhibit the managers' adverse selection and moral hazard. The specific measures include the optimization of director nomination mechanism, formation mechanism of the board, accountability 
and exoneration mechanism of the directors, and so on. So the board becomes a truly agency to exercise power independently and take on responsibility. The functions of professional Committee and the decision-making procedures of the board should be strengthened in order to provide information and technical support which on playing the board' central role.

4.3 The duties of supervisory board should be implemented to protect the financial control system from the design of corporate governance mechanism

For financial control system not being a mere formality, the key is to strengthen the supervision on implementation process. In the financial control framework, the audit committee under the board of directors and the audit department under the managers are playing a more and more significant role in monitoring and evaluating the running process of financial control system. However, the monitoring on the board of directors by the board of supervisors has a long-term weakening. Solution to this problem depends on strengthening function of the board of supervisors. The basic idea is to introduce stakeholders in the supervisory board and to distinguish the functions between independent directors and supervisors.

\section{References}

Beasley, M.S. (1996). An empirical analysis of the relation between the board of director composition and financial statement fraud. The Accounting Review.

Klein, A. (2002). Audit committee, board of director characteristics, and earnings management. Journal of Accounting and Economics.

La Porta, R., Florencio Lopez-de-Silanes and An drei Shleifer. (1999). Corporate Ownership around the World, Journal of Finance.

Warfield, T.D., John.J.Wild and Kenneth.L.Wild.Managerial ownership. (1995). Accounting choices and Informativeness of earnings. Journal of Accounting and Economics. 